\title{
Effect of organic and chemical sources of nitrogen and seedling age at transplant on growth and yield of Kohlrabi
}

\begin{abstract}
Use of chemical fertilizer is increasing with the perception of it being superior to organic manure. Many researches compared effect of different nutrient sources in different crops but still many gaps exist. Seedling age which highly effects on crop growth is a neglected research topic in horticulture with none in Kohlrabi. Research to find the significance of different nutrient sources and seedling age was carried out as a pot culture experiment on horticulture field of HASERA Agriculture Research and Training Center, Nepal during winter season of 2017/18. Research consisted of two factorial treatments. Five sources of nitrogen viz. i) Control, ii) Farm Yard Manure, iii)Poultry manure, iv)Goat manure and v) Chemical and two different seedling age viz. i) 14 days and ii) 28 days were replicated four time. The amount of each sources of nitrogen was adjusted to supply $2 \mathrm{~g}$ of nitrogen per plant. No significant effect of sources of nitrogen was found in growth (Height, Leaves, Swelling initiation and Cracking) and yield (Knob weight and Circumference) of Kohlrabi. Considering ecological consequences and nutrient release rates (33\% vs 93\%) organic sources are found better than chemical sources. Knob weight and circumference was significantly higher in 28days seedling $(79 \mathrm{~g}, 17.68 \mathrm{~cm})$ than 14 days seedling $(60 \mathrm{~g}, 15.4 \mathrm{~cm})$. Cracking in knob was significantly higher in 28 days seedling $(20 \%)$ than in 14days seedling $(0 \%)$. 14days seedling was found better in places where winter cracking is problem. No significant interaction effect was found between sources of nutrient and seedling age at transplant.
\end{abstract}

Keywords: cracking, kohlrabi, nutrient release rate, organic matter, seedling age
Volume 8 Issue 5 - 2018

\author{
Bibek Dhital, ${ }^{1,2}$ Amit Khanal,' Govinda \\ Sharma, ${ }^{2}$ Anusha Sharma' \\ 'Department of Horticulture, Institute of Agriculture and Animal \\ Science, Nepal \\ ${ }^{2}$ HASERA Agriculture Research and Training Center, Nepal
}

Correspondence: Bibek Dhital, Department of Horticulture, Institute of Agriculture and Animal Science, Nepal, Email Bibekdhitall2@gmail.com

Received: September 19,2018 | Published: October 26, 2018

\section{Introduction}

Kohlrabi (Brassica oleracea var. gongylodes), a member of the cole crops, which belongs to the family Cruciferae is of northEuropean origin. ${ }^{1}$ It is also known as Knolkhol German turnip, cabbage turnip, Navalkol, GunthGobhi, and Ganthgobhi ${ }^{2}$ and Olkapi. ${ }^{1}$ The bulb like swollen edible portion is stem known as knob, which arises from thickening of stem tissues above the cotyledon. ${ }^{2}$ This knob is harvested for human consumption as raw or cooked vegetable. One hundred gram of edible portion of kohlrabi contains $92.7 \mathrm{~g}$ moisture, $1.1 \mathrm{~g}$ protein, $0.2 \mathrm{~g}$ fat, $0.7 \mathrm{~g}$ minerals, $1.5 \mathrm{~g}$ fiber, $3.8 \mathrm{~g}$ carbohydrates, $25 \mathrm{cal}$. Energy, $20 \mathrm{mg}$ calcium, $18 \mathrm{mg}$ magnesium, $10 \mathrm{mg}$ oxalic acid, $35 \mathrm{mg}$ phosphorus, $0.4 \mathrm{mg}$ iron, $0.12 \mathrm{mg}$ sodium, $37 \mathrm{mg}$ potassium, $0.09 \mathrm{mg}$ copper, $143 \mathrm{mg}$ sulphur, $36 \mathrm{I}$.U. vitamin A, $0.12 \mathrm{mg}$ riboflavin, $0.5 \mathrm{mg}$ nicotinic acid, $0.05 \mathrm{mg}$ Thiamin, and $85 \mathrm{mg}$ Vitamin c. ${ }^{2}$ Production of Kohlrabi depends on many factors such as quality of seed, variety, plant spacing, types of manure and fertilizer and management practices. ${ }^{1}$ Kohlrabi is a winter crop whose growth is optimum at around 15-25 degree Celsius. Temperature drop below 15 degree Celsius for a longer period of time may cause bolting. Use of chemical fertilizer is increasing rapidly. ${ }^{3}$ Organic manures because of their bulkier nature are used less and are perceived as inferior to chemical fertilizers. Chemical supplement of nutrient is one way of nutrient replacement in soil but it has many demerits from soil health to water pollution, environmental and human health hazards. ${ }^{3}$ Subsidy in chemical fertilizers has increases uneconomical use of fertilizer and inefficient substitution for organic manures. ${ }^{4}$ The strategy of combating low yield with high external inputs of fertilizer and pesticides is in return increasing cost of production in small farms. ${ }^{5}$ Though organic manure supplies less amount of specific nutrient than chemical manure, it supplies all the necessary minerals and improves physical, biological and chemical properties of the soil. ${ }^{6}$ Researches on organic manures are mostly focused on the amount of manure applied rather than the amount that the manure supplies. When the amount of nitrogen supplied is made same, with different rates of Phosphorus and potassium there is insignificance in yield and other yield parameters. ${ }^{7}$ Slow nutrient releasing capacity of organic manures $33 \%{ }^{8}$ and massive loss of nutrients from chemical sources because of high release rates i.e. $93-100 \%{ }^{9}$ are factors to be considered for the long run. Seedling age has great potential on addressing different issues of crop growth cycle. The yield potential of seedling age has been commercially exploited only in rice till date ${ }^{10}$ and more diversity and replication of research are needed on vegetables to understand the physiology of seedling age in improving crop yield. ${ }^{10-17}$ This research was carried out to compare the yield potential of different nutrient sources when the amount of specific nutrient supplied is made constant. Seedling age being neglected topic in vegetables, this research attempts to explore the potential of seedling age on addressing issues of crop growth cycle.

\section{Material and methods}

The research was carried out in the fields of HASERA Agriculture Research and Training Center, Nepal during the winter of 2017/18. 
The GPS location of the farm is $27^{\circ} 35^{\prime} 24.2592^{\prime \prime} \mathrm{N}$ latitude and $85^{\circ}$ 35'30.0192" E longitude, 1452masl, 40KM from Kathmandu and $11 \mathrm{Km}$ from Dhulikhel on BP highway. Research was carried out as a pot culture experiment on horticulture field of HASERA Agriculture Research and Training Center, Nepal during winter season of 2017/18. Research consisted of two factorial treatments. Five sources of nitrogen viz. i)Control, ii)Farm Yard Manure, iii)Poultry manure, iv)Goat manure and v)Chemical and two different seedling age viz. i)14days and ii)28days which were laid out in Completely Randomized Design and replicated four time. The amount of each sources of nitrogen was adjusted to supply $2 \mathrm{~g}$ of nitrogen per plant. Soil for pot filling was dug from the subsoil region of one of the terrace of the research site. The dug soil was mixed properly to make homogenous distribution of residual nutrient from previous cropping season. Incorporation of different source of nitrogen was done 1 month prior to transplantation as the release rate of bulky manures is slow. Urea was applied on the day of transplantation. Seedlings were kept in two different lots at 14days interval. The $1^{\text {st }}$ seedling was kept on September 16th and the 2nd one was kept on September 30th. Transplantation of seedling was done on 14th October when the seedling from 16th September 28days old and another lot from 30th September 14days old. Data collection and observation was done for number of leaves, plant height, days to swelling initiation, knob fresh weight, knob circumference and knob cracking. Manually collected data were tabulated in excel sheet. The statistical difference between sample types were analyzed by TwoWay ANOVA using R Studio; $*=p<0.05: * *=p<0.01$ and Chi squared independence test using SPSS; $*=p<0.05: * *=p<0.01$. (Table 1)

Table I Amount of manure per pot

\begin{tabular}{|c|c|c|c|c|}
\hline S.N & Treatment & $\begin{array}{l}\text { Amount of } \\
\text { manure }\end{array}$ & Nitrogen \% & $\begin{array}{l}\text { Nitrogen } \\
\text { supplied }\end{array}$ \\
\hline I. & Control & - & - & \\
\hline 2. & FYM & $400 \mathrm{~g}$ & $0.5 \%$ & $2 \mathrm{~g}$ \\
\hline 3. & $\begin{array}{l}\text { Goat } \\
\text { manure }\end{array}$ & $67 g$ & $3 \%$ & $2.01 \mathrm{~g}$ \\
\hline 4. & $\begin{array}{l}\text { Poultry } \\
\text { Manure }\end{array}$ & $67 g$ & $3.03 \%$ & $2.03 \mathrm{~g}$ \\
\hline 5. & Chemical & $\begin{array}{l}100 \mathrm{~g} F Y M+20 \mathrm{~g} \\
\text { Poultry }+2 \mathrm{~g} \\
\text { Urea }\end{array}$ & $0.5 \%+3 \%+46 \%$ & $2.02 \mathrm{~g}$ \\
\hline
\end{tabular}

The requirement of nitrogen for Kohlrabi is $100 \mathrm{~kg}$ per hectare in addition with 20ton FYM (Singh, 2015). This 100ton FYM gives $100 \mathrm{~kg}$ Nitrogen $@ 0.5 \%$ (TNAU, N/A). With the planting geometry of $40 \mathrm{~cm}^{*}$ (Singh, 2015), the amount of nitrogen is $2 \mathrm{~g}$ per plant. Amount of different organic manure were so chosen so as to make the amount of nitrogen supplied same. The content of nitrogen was measured at FYM $0.5 \%$, goat manure $3 \%$ and Poultry manure $3.03 \%$ (TNAU, N/A)

\section{Results and discussion}

\section{Results}

The results of the research are presented below

\section{Effect on number of leaves and plant height (Table 2)}

There was no significant effect of the source of nitrogen and seedling age at transplant on number of leaves and plant height at
HASERA Agriculture Research and Training Center, Nepal in 2018. There was no significant effect of the source of nitrogen and seedling age at transplant on number of leaves and plant height. plant height. Also the interaction of source of nitrogen with seedling age was found insignificant. Insignificance of different manure sources in plant height in kohlrabi was mentioned by Uddain. ${ }^{18} \mathrm{Ahmed}^{7}$ reported insignificance of different phosphorus and potassium combinations in leaves number when amount of nitrogen was made constant. Khandaker ${ }^{19}$ mentioned different types of manure (NPK, Poultry and goat) didn't have significant effect on plant height of okra. Effect on swelling initiation, Knob circumference and Knob Yield Table 3: Effect of different source of nitrogen and seedling age at transplant on swelling initiation, fresh weight and circumference of the knob at harvest in Kohlrabi at HASERA Agriculture Research and Training Center, Nepal in 2018. Source of nitrogen had no significant effect on days to swelling initiation, fresh weight and knob diameter. All treatments performed significantly higher than control in terms of fresh weight and knob circumference. Seedling age has significant effect on days to swelling initiation, fresh weight and knob circumference. 28days old seedling started to swell early (12.8days) had higher knob circumference $(17.68 \mathrm{~cm})$ and fresh weight $(79 \mathrm{~g})$ compared to 14days old seedling which took 19.52days to swelling initiation and gave smaller fruits of only $60 \mathrm{~g}$ and $17.68 \mathrm{~cm}$ circumference. Uddain ${ }^{18}$ reported insignificance of different sources of manure in yield and diameter and $\mathrm{Ahmed}^{7}$ also reported insignificance of different $\mathrm{P}$ and $\mathrm{K}$ combination in yield and diameter when Nitrogen is made constant.

Table 2 Effect of different source of nitrogen and seedling age at transplant on number of leaves and plant height at HASERA Agriculture Research and Training Center, Nepal in 2018

\begin{tabular}{lll}
\hline Source of nitrogen (SoN) & Number of leaves & Plant height \\
\hline Control & 8.25 & 15.25 \\
FYM & 9.375 & 16.87 \\
Goat & 8.625 & 16.25 \\
Poultry & 9 & 17.5 \\
Chemical & 9.625 & 19.43 \\
Seedling Age & & \\
I4days & 9.05 & 17.625 \\
28days & 8.9 & 16.5 \\
P Value & & \\
SoN & 0.0904 & 0.167 \\
days & 0.6555 & 0.298 \\
SoN*Days & 0.3987 & 0.884 \\
\hline
\end{tabular}

\section{Effect on knob cracking}

(Table 4) The parameters are analyzed using chi square independence test and $p<0.05$ denotes statistical significance between observation Cracking in kohlrabi is caused due to different conditions of soil moisture, soil temperature and/or soil nutrient content. There is no significant relationship between source of nitrogen and cracking in kohlrabi, $\chi^{2}(4,80)=6.389, \mathrm{p}=0.172$, while highly significant relationship between seedling age and cracking in kohlrabi, $\chi 2(1$, $80)=8.889, \mathrm{p}=0.003$ was found. 28 days old seedlings are more likely to crack than 14 days old seedling ( $20 \%$ to $0 \%$ ). 
Table 3 Effect of different source of nitrogen and seedling age at transplant on swelling initiation, fresh weight and circumference of the knob at harvest in Kohlrabi at HASERA Agriculture Research and Training Center, Nepal in 2018

Values within same column with a common letter as superscript do not differ as a statistical significance of $*=p<0.05 ; * *=p<0.0$ I. In Duncan's test

\begin{tabular}{llll}
\hline Source of & Days to swelling & Diameter $(\mathbf{c m})$ & Fresh weight $\mathbf{( g / k n o b})$ \\
\hline Nitrogen (SoN) & & & \\
Control & 15.6875 & $14.03125 \mathrm{~b}$ & $43.7500 \mathrm{~b}$ \\
FYM & 15.1875 & $17.09375 \mathrm{a}$ & $72.8125 \mathrm{a}$ \\
Goat & 16.375 & $17.45625 \mathrm{a}$ & $82.5000 \mathrm{a}$ \\
Poultry & 16.4375 & $17.68750 \mathrm{a}$ & $75.0000 \mathrm{a}$ \\
Chemical & 17.125 & $16.93750 \mathrm{a}$ & $74.6875 \mathrm{a}$ \\
Seedling age & & & \\
I4days & $19.525 \mathrm{a}$ & $15.6000 \mathrm{~b}$ & $60.5 \mathrm{~b}$ \\
28 days & $12.8 \mathrm{~b}$ & $17.6825 \mathrm{a}$ & $79.0 \mathrm{a}$ \\
Level of significance & & & \\
SoN & 0.614 & $0.00260^{* *}$ & $0.000423^{* *}$ \\
Days & $0.000^{* *}$ & $0.00122^{* *}$ & $0.00100 I^{* *}$ \\
SoN*Days & 0.214 & 0.59428 & 0.297084
\end{tabular}

The parameters are analyzed using chi square independence test and $\mathrm{p}<0.05$ denotes statistical significance between observation

Table 4 Effect of different source of nitrogen and seedling age at transplant on cracking of Kohlrabi knob at HASERA Agriculture Research and Training Center, Nepal in 2018

The parameters are analyzed using chi square independence test and $p<0.05$ denotes statistical significance between observation.

\begin{tabular}{lllll}
\hline Cracking/ Source of nitrogen & Yes & No & Pearson chi square coefficient & Level of significance (p) \\
\hline Control & 4 & 12 & 6.389 & 0.172 \\
FYM & 0 & 16 & & \\
Goat & 2 & 14 & & \\
Poultry & 1 & 15 & & \\
Chemical & 1 & 15 & & $0.003^{* *}$ \\
Cracking/Seedling & Yes & No & \\
\hline Age & & & & \\
I4days & 0 & 40 & 8.889 & \\
28 days & 8 & 32 & & \\
\hline The parameters are analyzed using chi square independence test and $p<0.05$ denotes statistical significance between observation.
\end{tabular}

\section{Discussion}

Many literatures suggest significant yield difference in different source of manure in which the amount of manure applied is considered rather than the amount of nutrient supplied. Premsekhar ${ }^{20}$ mentioned FYM being significantly superior in okra cultivation. Maurya (2008) in broccoli, Moyin Jesu ${ }^{21}$ in cabbage, Michael (2017) in carrot, Bacha ${ }^{22}$ in mustard, found poultry manure to have significantly superior yield. Increasing oil content with increasing FYM was reported in mustard by Gupta (2012). Kiran ${ }^{23}$ mentioned chemical sources to have significant higher yield in carrot and poultry manure to have superiority over other organic sources. Chemical sources release as much as $93 \%$ to $100 \%$ of urea in the same growing season, ${ }^{9}$ While in organic sources, as much as two third of nitrogen and one half of phosphorus may not be available to the plants in the same season because of slow decomposition. ${ }^{8}$ Whit this difference in nutrient release rates, if organic sources yield statistically at par with chemical fertilizers, we can suggest organic sources to have high benefit over chemical sources. Also considering the ecological consequences of chemical fertilizers ${ }^{24}$ organic sources have environmental advantage over chemical sources of nitrogen. Temperature drop below 15 degree Celsius (Singh 2015) and below 12 degree celcius ${ }^{25}$ for a longer period of time may cause bolting in Kohlrabi which might be the reason for cracking. Cracking in Kohlrabi is due to physical properties of epidermal cells and turgor pressure of parenchymatous cells which is induced by climatic factors (Lippet, 1999). Climatic factors such as exposing in low temperature for prolonged time can cause cracking during post-harvest handling of fruits and vegetable which is due to volume expansion and pressure buildup (BarbosaCánovas. 2005). Cracks can also be induced by uneven or slow growth and development which can be result of many physical, chemical, climatic or biological factors (Fontenot 2005). Freezing injury causes cracks in carrot, trees with thin bark such as peach and maple and also in fruits and fruit trees. ${ }^{26}$ Fluctuation in the available soil moisture may lead to growth cracks. ${ }^{27}$ In Kohlrabi cracking is also caused by rain. ${ }^{28}$ Limited research has been carried out regarding 
seedling age in kohlrabi. Significantly difference performance among different cultivars regarding seedling age has been reported by Arun et al. ${ }^{29}$ In his research consisting two seedling age (4week and 6week) and three cultivars, 6week old seedling of Cultivar E. forcer showed higher tuber weight $(215.7 \mathrm{gm})$, tuber diameter $(76.4 \mathrm{~cm})$ and yield (5.44g) compared to 4week old seedling. Whereas in cultivars Neckar and Lahn, no significant difference was seen different seedling age. Among 4week and 6week old seedling, 4week old seedling performed significantly better in terms of weight. Diameter and yield. ${ }^{29}$

In review by Vivriana ${ }^{10}$ Insignificance of seedling age in different growth parameter is mentioned by Nesmith ${ }^{14}$ in summer squash, Nesmith $^{15}$ in muskmelon, Vavriana ${ }^{30}$ in watermelon, Leskovar ${ }^{11}$ and Jankauskiene $^{31}$ in tomato, Weston (1998) in pepper and Lamount (1992) in broccoli. 20-24days old seedling was found to give maximum return compared to 16days and 28days seedling. 40days old seedling, which was youngest of all treatment, was recommended in cucumber by Jellani. ${ }^{32}$ Jones $^{12}$ suggested older seedling of 5 weeks to have higher yield in cauliflower but Lamount (1992) mentioned no significant difference between seedlings from two to six weeks old. Limited researches are found relating seedling age in horticultural crops. ${ }^{10,33}$ More research and replication are necessary to exploit the potential of younger seedling in different crops. ${ }^{13}$

\section{Conclusion}

Considering all the circumstances, organic sources of nitrogen were found better compared to chemical sources. Any form of organic manure can give superior yield if the amount of nutrient supplied is considered. 28days old seedling is found to give higher yields but 14days old seedling is found better in those areas where cracking is seen as a major problem.

\section{Acknowledgements}

I would like to offer my sincere thanks to HASERA Agriculture research and Training Center, Institute of Agriculture and Animal Science, all of my friends and family helping directly or indirectly for the completion of this research.

\section{Conflict of interest}

Author declares that there is no conflict of interest.

\section{References}

1. J Sultana, MA Siddique, MHA Rashid. Effects of cowdung and potassium on growth and yield of Kohlrabi. J Bangladesh Agril Univ 2012;10(1):2732.

2. Nagar G. Effect of varieties and nutrient levels on growth, yield and quality in knolkhol (Brassica oleracea var. gongylodes L.). Department of Vegetable Science. Rajmata Vijayaraje Scindia Krishi Vishwa Vidyalaya, Gwalior; 2016.

3. FAO. Fertilizer Use to Surpass 200Million Tonnes in 2018. Food and Agriculture Organization of the United Nations. 2015.

4. Crawford EW, TS Jayne, VA Kelly. Alternative Approaches for Promoting Fertilizer Use in Africa. Agriculture and Rural Development Discussion Paper 22. World Bank. 2006.

5. Florentín MA, M Peñalva, A Calegari, et al. Green manure/cover crops and crop rotation in conservation agriculture on small farms. Food and Agriculture Organization (FAO). Integrated Crop Management. 2010:12.

6. Han SH, JY An, JH Se, et al. The effects of organic manure and chemical fertilizer on the growth and nutrient concentrations of yellow poplar (Liriodendron tulipifera Lin.) in a nursery system. Forest Science and Technology. 2016;12(3):137-143.
7. Ahmed S, F Ahmed, F Hussain, et al. Effect of Different NPK Levels on the Growth and Yield of Kohlrabi (Brassica caulorapa L.) at Northern Areas of Pakistan. Asian Journal of Plant Sciences. 2003;2(3):336-338.

8. Thapa M. Factors affecting fertilizer use efficiency in dry season paddy production in Makawanpur district, mid hill, Nepal. Agronomy Journal of Nepal. 2010;1:123-133.

9. Campos OR, EM Mattiello, RB Cantarutti, et al. Nitrogen release from urea with different coatings. $J$ Sci Food Agric. 2018;98(2):775-780.

10. Vavriana C. Transplant Age in Vegetable Crops. Hort Technology. 1998;8(4):550-555.

11. Leskovar DI, J Cantliffe. Growth and Yield of Tomato Plants in Response to Age of Transplants. J Amer Soc Hort Sci. 1991;116(3):416-420.

12. Jones T, LA Weston, R Harmo. Effect of root cell size and transplant age on cole crop yields. Hort Science. 1991;26(6):688.

13. Lamont WJ. Transplant age has little effect on broccoli head weight and diameter. Hort Science. 1992;27(7):848.

14. NeSmith DS. Transplant age influences summer squash growth and yield. Hort Science. 1993;28(6):618-620.

15. Nesmith DS. Transplant Age Has Little Influence on Yield of Muskmelon (Cucumismelo L.). Hort science. 1994;29(8):916.

16. Tanweer S, IA Hafiz, N Abbasi, et al. Effect of Seedling Age and Different Levels of Phosphorus on Growth and Yield of Cucumber (Cucumissativus L). Int J Agri Biol. 2005;7(2):311-314.

17. Jaiswal AK, JP Singh, S Tomar, et al. Effect of Seedlings Age on Growth. Yield Attributes and Yield of Tomato Lycopersiconesculentum Mill. International Journal of Current Microbiology and Applied Sciences. 2017;6(9):1521-1524.

18. Uddin J, AHM Solaiman, M Hasanuzzaman. Plant Characters and Yield of Kohlrabi (Brassica oleraceae var. gongylodes) as Affected by Different Organic Manures. Journal of Horticultural Science \& Ornamental Plants. 2009;1(1):1-4.

19. Khandaker MM, N Jusoh, NH Ralmi, et al. The effect of different types of organic fertilizers on growth and yield of Abelmoschusesculentus 1. Moench (okra). Bulgarian Journal of Agricultural Science. 2017;23(1):119-125.

20. Premsekhar M, Rajashree V. Influence of Organic Manures on Growth, Yield and Quality of Okra: Am. Eurasian J Sustain Agric. 2009;3(1):6-8.

21. Moyin-Jesu EI. Use of different organic fertilizers on soil fertility improvement, growth and head yield parameters of cabbage (Brassica oleraceae L). Int J Recycl Org Waste Agricult. 2015;4:291-298.

22. Bacha SAS. Effect Of Organic Fertilizers On Growth And Yield Of Brassica Rapa Variety Chinensis. Advances in Environmental Biology. 2016;10(10):40-46.

23. Kiran M, MS Jilani, K Waseem, et al. Response of Carrot (Daucuscarota L.) Growth and Yields to Organic Manure and Inorganic Fertilizers. American Eurasian J Agric \& Environ Sci. 2016;16(6):1211-1218.

24. Adhikari P. Effect of different doses of organic manure on growth and yield of sweet pepper. Tribhuvan University. Institute of Agriculture and Animal Science. Nepal; 2015.

25. Wiebe HJ, HP Liebig. Temperature control to avoid bolting of kohlrabi using a model of vernalization. International society for horticulture Science. 1989.

26. Caplan LA, V County. Effects of Cold Weather on Horticultural Plants in Indiana. Department of Horticulture. Purdue University Cooperative Extension Service. 2012.

27. Ontario. Kohlrabi. Speciality crop opportunities. A resource for Speciality Crop Growers. 2012. 
28. Thiessin Farms. 2017.

29. Arın L, Salk A, Deveci M, et al. Kohlrabi growing under unheated glasshouse conditions in Turkey. Acta Agric Scand B. 2003;53:38-41.

30. Vavrina CS, S Olson, S Oslon, et al. Watermelon transplant age: Influence on fruit yield. Hort Science. 1993;28(8):789-790.

31. Jankauskiene J, A Brazaityto, Y Bobinas, et al. Effect of transplant growth stage on tomato productivity. Acta Sci Pol Hortorum Cultus. 2013;12(2):143-152.
32. Jellani G, MJ Atif, H Ullah, et al. Seedling age and Impact on Growth and Yield of bitter gourd. Science, Technology and Development. 2016;35(2):94-97.

33. Aguiar JL. Symptoms of frost, freezing and chilling injury on vegetables. Western Farm press. 2012. 